\title{
Exploring the Spatial Variation of the Relationship between Land Use and Water Quality in a Drainage Basin Using Geographically Weighted Regression
}

\author{
Samuel Azua ${ }^{1}$ \\ Taiye Oluwafemi Adewuyi ${ }^{2}$ \\ Lazarus Mustapha Ojigi ${ }^{3}$ \\ Omafuvwe Joseph Mudiare ${ }^{4}$
}

\begin{abstract}
The focus of this study is to determine the relationship between land use and water quality in the River Mu drainage basin for effective water quality management. Various land uses in the study area were identified and mapped using Landsat 8 OLI of 2016. Water samples were also collected from 112 sample sites using Stratified Random Sampling methods. The samples were analysed in terms of physicochemical parameters using standard methods. The results of land use and water quality parameters were regressed using Geographically Weighted Regression (GWR) to determine whether there exist spatially varying relationships. The results revealed that the local $R^{2}$ values varied between 0.0 and 0.5 , indicating a weak relationship between land use and water pollution, except for mixed forest and $p H$ which recorded local $R^{2}$ values of 0.7 towards the western region of the study area. This shows that the relationship between the two variables varied spatially across the drainage basin. The one-sample Kolmogorov Smirmov test-p $<0.05$ revealed that there were significant differences in $\mathrm{pH}(0.00), \mathrm{EC}(0.00)$, turbidity (0.001), TDS (0.048), DO (0.003), $\mathrm{NH}_{4}^{+}(0.002), \mathrm{Ca}^{2+}(0.00), \mathrm{Cl}^{-}(0.036), \mathrm{Fe}^{3+}(0.00)$ and $\mathrm{Cr}^{2+}(0.039)$ across the different sample points, whereas $\mathrm{K}^{+}(0.134), \mathrm{PO}_{4}^{3-}(0.715)$ and $\mathrm{NO}_{3}^{-}(0.501)$ were not significantly different across the different sample points. The study recommended that the procedure for water management be localized to sub-catchment and basin levels, to provide adequate attention to each sub-catchment depending on the level and nature of pollution identified.
\end{abstract}

Keywords: Geographically Weighted Regression, Land use, River Mu drainage basin, Spatial Variation, Water quality.

\footnotetext{
${ }^{1}$ Department of Geomatics, Ahmadu Bello University, Zaria, ${ }^{2}$ Department of Geography, Nigerian Defense Academy, Kaduna, ${ }^{3}$ Department of Agricultural Engineering, Ahmadu Bello University, Zaria, Correspondence Email: adzuasamuel@yahoo.com
}

Ghana Journal of Geography Vol. 12 (2), 2020 pages 147- 168

https://dx.doi.org/10.4314/gjg.v12i2.7 


\section{Background}

Land use is an integral part of human existence without which life can be meaningless. Land use activities such as farming, cattle rearing, settlements and industry, amongst others, support life by providing its basic necessities. As good as this may be, these activities create many environmental problems that have significant effects on the health of humans and the environment (Azua, 2018). One of these problems may be pollution of surface water used for domestic, agriculture and industrial purposes (Roberts and Prince, 2010; Badmus, Ozebo, Idowu, Ganiyu and Olurin, 2014). Accordingly, Li, Song and Wu, (2009) and Huang, Huang, Pontius Jr. and Zhang, (2015) reported a strong correlation between land use and surface water pollution. It is therefore very important to assess the relationship between land use and water pollution, particularly in river basins, for effective management of these resources.

In view of the above, many researchers have assessed the relationship between land use and water pollution. Tu (2011) analysed the spatially varying relationships between land use and water quality in Metropolitan Boston in eastern Massachusetts, United States of America (USA), using GWR. The study parameters were regressed to determine whether there exists a varying relationship. Findings established significant relationship between the six land uses and fourteen water quality parameters utilized. Further observation revealed that there is a positive correlation between the water pollutant concentrations and urbanized lands.

In China, Ding, Jiang, Fu, Liu, Peng and Kang, (2015) analysed the effects of land use on Dongjiang River basin surface water quality. The study reported negative correlation between forest land use and surface water nutrients. In addition, the dry season revealed a higher impact on the Dongjiang basin water quality by forest and urban land use. Other literature considered in this study include Tu, Xia and Clarke (2007), Tran, Bode and Smith, (2010), Gyawali, Techato, Yuangyai and Musikavong, (2013) and Chu, Liu and Wang, (2013).

Most of these studies focused on the conventional statistics methods such as Spearman's rank and Pearson correlation to identify relationships between land use and water quality (Bahar, Ohmori and Yamamuro, 2008; Sun, Huang and Hong, 2011; Huang et al., 2015). However, Huang et al. 
Exploring the Spatial Variation of the Relationship between Land Use and Water Quality in a Drainage Basin Using Geographically Weighted Regression

(2015) noted that these relationships may vary across the study area depending on land use, hence, the global models employed in most of the studies above do not have the capability to address the spatial varying relationship targeted. This is because the global relationship assumes that the relationship is homogeneous across space and in this case, across the river basin.

Geographically Weighted Regression (GWR) is one of the models designed by Fotheringham, Brunsdon and Charlton, (2002) to deal with local relationships. This model is used to ascertain the existence of a spatially varying relationship between variables (Fotheringham et al., 2002 in Lloyd 2010; Naibbi and Healey, 2014; Sabokbar, Roodposhti and Tazik, 2014). This is contrary to the conventional ordinary least squares regression which deals with one relationship for the entire study area.

In Nigeria, it appears that the application of GWR in research is not widely known, because only a few studies have explored the use of this model. For instance, Ismaila (2013) used GWR to determine the relationship between land use change and its associated factors. Similarly, Naibbi and Healey (2014) used it to evaluate the spatial patterns of fuelwood utilization in Nigeria. Hence, there is paucity of literature on the spatial variations of relationships between land use and water pollution in river basins of Nigeria. Studies of this nature are very important for the management of drainage basins in Nigeria and Benue State in particular where most people depend on fresh water from rivers for domestic use and other purposes.

The objective of this study is to analyse the spatial variation of relationships between land use and water quality in the River Mu drainage basin using the GWR model. This was achieved through the identification and mapping of the various land uses in the area, acquisition and analyses of water samples from which the spatial relationships between the variables were determined.

\section{The Study Area}

River Mu is one of the tributaries of River Benue that passes through many communities. It serves as a major source of water for domestic, agriculture and industrial purposes. This river mostly dries up during the dry season leaving only pools of water in areas that have deep ditches (Elaigwu, 
Okayi and Oshoke, 2013). The River Mu drainage basin is located within Latitudes $7^{\circ} 17^{\prime}$ and $7^{\circ}$ $44^{\prime} \mathrm{N}$ and Longitudes $8^{\circ} 34^{\prime}$ and $8^{\circ} 57^{\prime} \mathrm{E}$ in North Central Nigeria, and has an average elevation of about 140m above mean sea level (Figure 1). It is a sub basin of the Lower Benue River Basin that is located west of River Benue covering an area of 136, 136.759 hectares. it has an estimated population of 52,120 (based on NPC, 2006). The River Mu basin covers parts of three Local Government Areas which spread across Gboko, Gwer East and Makurdi.

The study area experiences a tropical climate characterized by dry and wet seasons. The dry season lasts for a minimum of five months (November-March) and is characterized by the harmattan that brings cold-dry and dusty wind that blows over the West African sub-region, making visibility in most areas difficult. The wet season lasts from April to October and is characterized by rainfall that has an average of 1300mm per year (Ologunorisa and Tor, 2006; Hula, 2010). Temperatures are generally very high especially during the day ranging between $16^{\circ}$ and $37^{\circ} \mathrm{C}$, particularly in March and April. The drainage basin falls within the Guinea Savannah region which is the largest vegetation class that covers almost half of Nigeria. Though, the area has high drainage density, some of it are seasonal, so that in some places there is no water during the dry season (Elaigwu $e t$ al., 2013).

The main occupation of the people in this area is farming. Large quantities of crops are produced which serve as a major source of food for the entire populace, provide raw materials for all agrobased industries and serves as a major source of income to farmers in the region who export the crops to other states and neighboring countries (Okwoche, Age and Alegwu, 2012). 
Exploring the Spatial Variation of the Relationship between Land Use and Water Quality in a Drainage Basin Using Geographically Weighted Regression

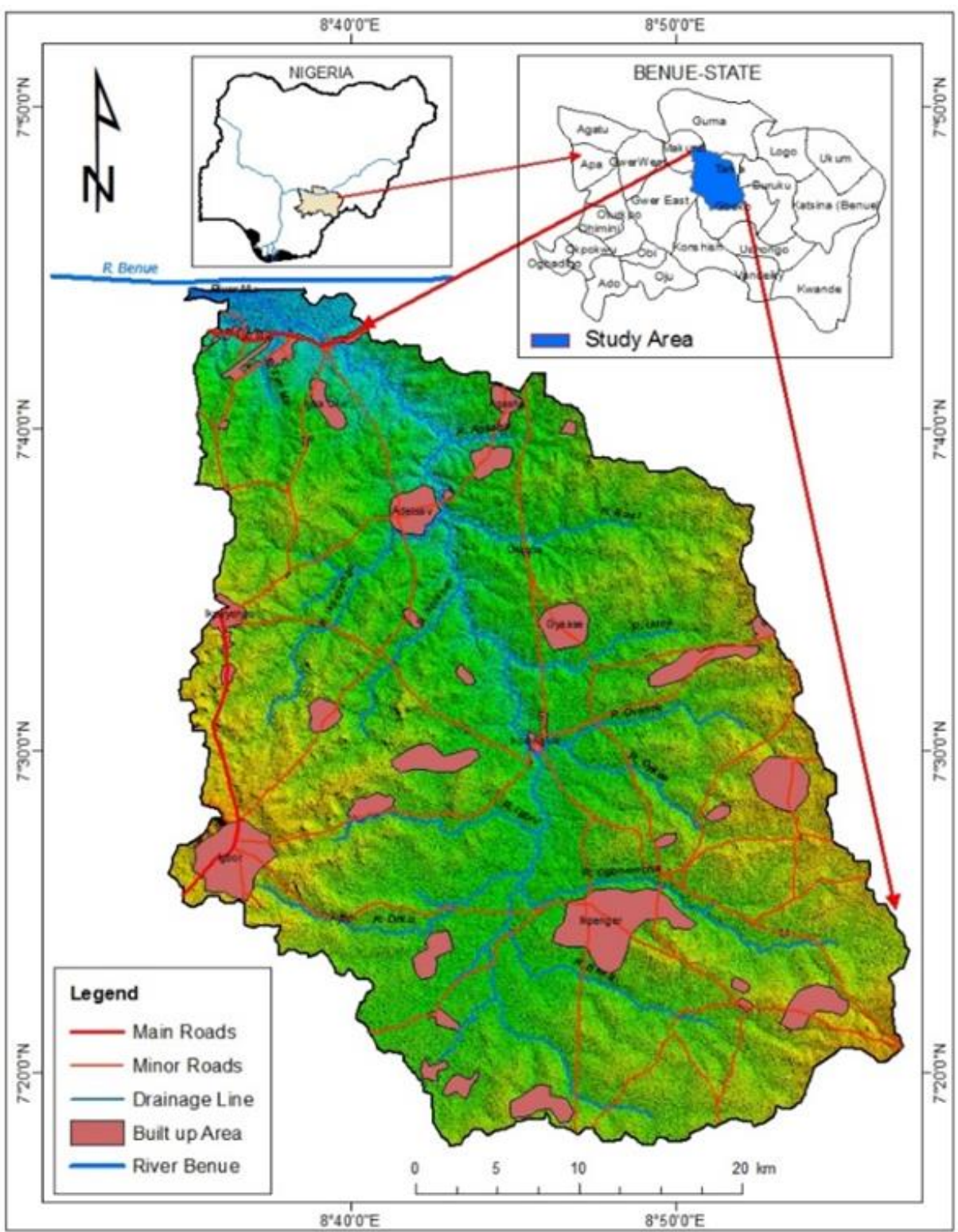

Figure 1: Mu Drainage Basin 


\section{Materials and methods}

\section{Materials Used}

The following materials shown in Table 1 were used for data collection during the course of this study.

Table 1: Materials and Equipment Used

\begin{tabular}{lll}
\hline Material/Equipment & Model & Purpose \\
\hline Plastic containers & - & Water Samples \\
Hand-held GPS & GARMIN GPSMAP 765CSX & Coordinates \\
Extech pH Meter & Hannah Instrument (PH100) & $\mathrm{pH}$ \\
Auto Ranging & Hannah Instrument & Electrical Conductivity, Total Dissolved \\
EC/TDS/Temperature & (HI9835 HI98360) & Solid and Temperature \\
Auto Ranging & Hannah Instrument & Dissolved Oxygen \\
DO/Temperature & (HI9835 HI98360) & \\
\hline
\end{tabular}

\section{Methods}

The basin was mapped using the hydrological model in ArcGIS 10.3 software to determine the extent of the study area. In order to identify the various land uses in the study area, a Landsat 8 OLI satellite image of 2016 was acquired on $29^{\text {th }}$ January 2016. The image was clipped to the boundary of the study area and subjected to digital image processing using histogram equalization to enhance the image contrast. The False Colour Composite (FCC) using bands 5, 4 and 3 was used to create the classified image employing the supervised classification in ERDAS Imagine 9.2.

Thereafter, surface water samples from 112 sample sites located within the drainage basin were collected from May 2015 to February 2016 at the interval of three months, using Nigeria's hydrological year calendar. The samples were collected in clean plastic bottles as recommended by Ahaneku and Animashaun (2013). The bottles were first sterilized using the Giant Autoclave at $120^{\circ} \mathrm{C}$ and also rinsed with the water at the point of collection to ensure that the containers were free from contamination. The samples were collected at about $20 \mathrm{~cm}$ below the water surface to 
Exploring the Spatial Variation of the Relationship between Land Use and Water Quality in a Drainage Basin Using Geographically Weighted Regression

ensure proper representation at that point (Akaahan, Leke and Eneji, 2015). The river water $\mathrm{pH}$, temperature, EC, TDS and DO were determined in situ using handheld instruments as described in Table 1, because these parameters have the tendency of changing their characteristics over time once collected from the main river. The remaining parameters were analysed using standard procedures as contained in Standard Methods for Water and Wastewater Examination (APHA, 1999).

After obtaining the land use and water parameters, GWR was employed to determine the relationship between the variables. GWR is based on the traditional linear regression methods (Eq. 1) as elucidated in Lu, Mei, Zhang, Liao, Long, Dahlgren, and Zhang, (2011):

$$
y_{i}=\beta_{o}+\sum_{i=1}^{k} \beta_{k} x_{i k}+\xi_{i}
$$

where:

$x_{i}$ and $\mathrm{y}_{i}=$ are respectively the independent and dependent variable;

$k=$ the number of independent variables;

$\beta_{o}$ and $\beta_{k}=$ are the intercept and coefficients, respectively; and

$\zeta_{i}=$ the error.

GWR is defined as when the measurement of relationships among variables differs from location to location (Fotheringham et al., 2002). This model was applied in this research because there is the propensity for the relationships between anthropogenic disturbances and water pollution to vary across a given area (Huang et al., 2015). The model is shown in Eq. 2 (Lu et al., 2011):

$$
y_{j}=\beta_{o}\left(u_{j}, v_{j}\right)+\beta_{k}\left(u_{j}, v_{j}\right) x_{j k}+\xi_{j}
$$

where:

$y_{j}=$ the estimated value of the dependent variable for observation $j$

$u_{j}, v_{j}=$ the coordinates of the location of the observation $j$;

$\beta_{o}\left(u_{j}, v_{j}\right)=$ the int ercept for sampling site $j$;

$\beta_{k}\left(u_{j}, v_{j}\right) x_{j k}=$ the local parameter estimate for sampling site $j$; and

$\xi_{j}=$ the error term for sampling site $j$. 
Each land use was categorised as an independent variable and the water pollutants as the dependent variable. This enables one to analyse the relationship between anthropogenic disturbance and the water quality at each location in the study area. The mean value of four water samples at each sample site was determined to obtain the result of each pollutant in a sample site. The purpose of this step was to do away with temporal variation in order to focus on the analysis of spatial variability (Huang et al., 2015).

Before embarking on the use of the GWR approach, the Pearson correlation was adopted to establish if there exists a relationship between the dependent and the independent variables in the area. During the use of this model, the following parameters were employed: Adaptive Kernel, local $\mathrm{R}^{2}$, local residuals and standard residuals (Javi, Malekmohammadi, and Mokhtari, 2013). In order to determine whether the independent variable could show the variance in the dependent variable, the local $\mathrm{R}^{2}$ values (coefficient of determination), were employed (Huang et al., 2015). The local $\mathrm{R}^{2}$ values usually range from 0 to 1 . Values of $\mathrm{R}^{2}$ close to 1 show that the independent variable can explain the spatial variance of the dependent variable (Javi et al., 2013; Huang et al., 2015). The local $\mathrm{R}^{2}$ and local residuals were analysed to determine the changes in relationships between the dependent and independent variables across the study area. All the analyses were carried out using ArcGIS 10.3.

\section{Results}

The result of the classification identified six (6) land use classes in the study area, namely built up, forest, mixed forest, agricultural lands, bare lands and exposed rocks as shown in Figure 2. The result of the accuracy assessment showed that the overall accuracy was 95\% while the Kappa coefficient was $73 \%$.

Table 2 shows the twelve water quality variables used for the analysis. The descriptive statistics for the study period indicating the maximum, minimum and mean values and standard deviation

of the parameters. The table also indicates the overall mean of each parameter for wet and dry seasons. The high standard deviation observed in some of the parameters indicates spatial 
Exploring the Spatial Variation of the Relationship between Land Use and Water Quality in a Drainage Basin Using Geographically Weighted Regression

variability in the chemical composition among the samples (Kilonzo, Masese, Griensven, Bauwens, Obando and Lens, 2014).

Table 2: Descriptive Statistics of the Measured Water Physicochemical Parameters

\begin{tabular}{|c|c|c|c|c|c|c|c|}
\hline Parameters & Min & Max & Mean & Std. Dev & $\begin{array}{l}\text { Mean in Wet } \\
\text { Season }\end{array}$ & $\begin{array}{l}\text { Mean in Dry } \\
\text { Season }\end{array}$ & $\begin{array}{l}\text { WHO } \\
\text { Standard }\end{array}$ \\
\hline Ammonia $((\mathrm{mg} / \mathrm{l})$ & 0.04 & 0.48 & .22 & 0.05 & 0.22 & 0.22 & 0.2 \\
\hline Calcium (mg/l) & -1.88 & 337.90 & 95.81 & 58.86 & 76.02 & 116.88 & $75-200$ \\
\hline Chloride (mg/l) & 0.19 & 32.09 & 9.57 & 5.33 & 9.810 & 9.43 & 250 \\
\hline $\mathrm{DO}(\mathrm{mg} / \mathrm{l})$ & 0.237 & 43.80 & 7.17 & 6.51 & 5.41 & 8.98 & $8-10$ \\
\hline $\mathrm{EC}(\mu \mathrm{S} / \mathrm{cm})$ & 12.321 & 289.90 & 87.34 & 52.82 & 77.69 & 98.16 & 1000 \\
\hline Nitrate $(\mathrm{mg} / \mathrm{l})$ & 0.336 & 10.00 & 3.50 & 1.71 & 4.01 & 3.03 & 50 \\
\hline $\mathrm{pH}$ & 1.209 & 9.33 & 7.44 & 1.21 & 7.60 & 7.43 & $6.5-8.5$ \\
\hline Phosphate (mg/l) & 0.111 & 13.03 & 3.09 & 2.59 & 3.45 & 2.75 & 0.5 \\
\hline Potassium (mg/l) & 0.63 & 19.20 & 4.20 & 3.38 & 4.26 & 4.21 & NIL \\
\hline TDS (mg/l) & 6.338 & 176.79 & 46.70 & 32.12 & 45.10 & 48.93 & 500 \\
\hline Temperature $\left({ }^{\circ} \mathrm{C}\right)$ & 4.1 & 34.50 & 27.63 & 4.44 & 27.13 & 28.75 & 25 \\
\hline Turbidity (NTU) & 3.121 & 37.90 & 14.14 & 9.17 & 18.73 & 9.73 & 5 \\
\hline
\end{tabular}




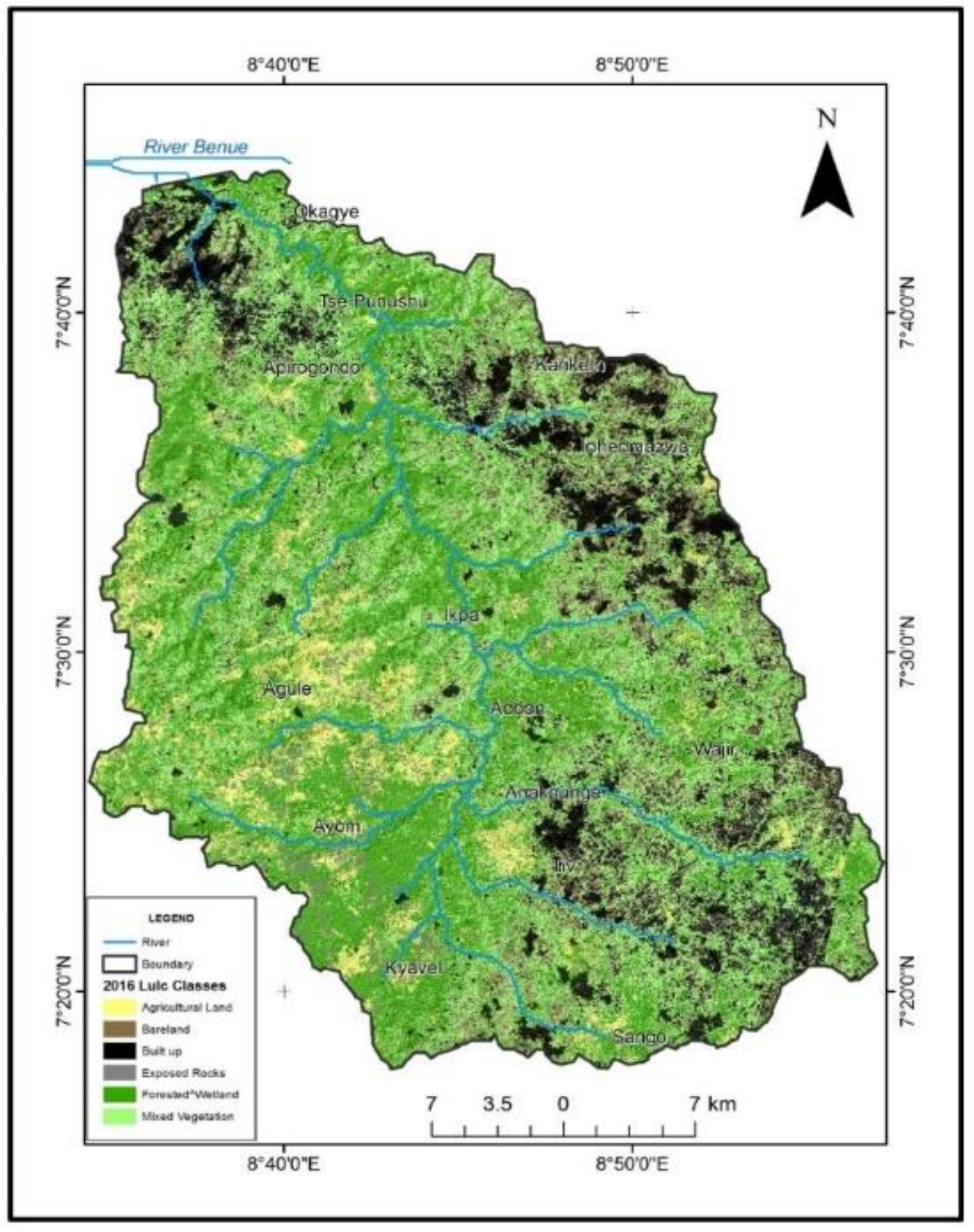

Figure 2: Land Cover in 2016

\section{Spatial Variation of land Use Categories}

The various land uses mapped in each of the 12 sub-catchment areas of the basin are shown in Figure 3. Six land use variables were identified. This was achieved by determining the percentages 
Exploring the Spatial Variation of the Relationship between Land Use and Water Quality in a Drainage Basin Using Geographically Weighted Regression

of each land cover in each sub-catchment. The bar charts represent the percentages of various land uses in each sub-watershed.

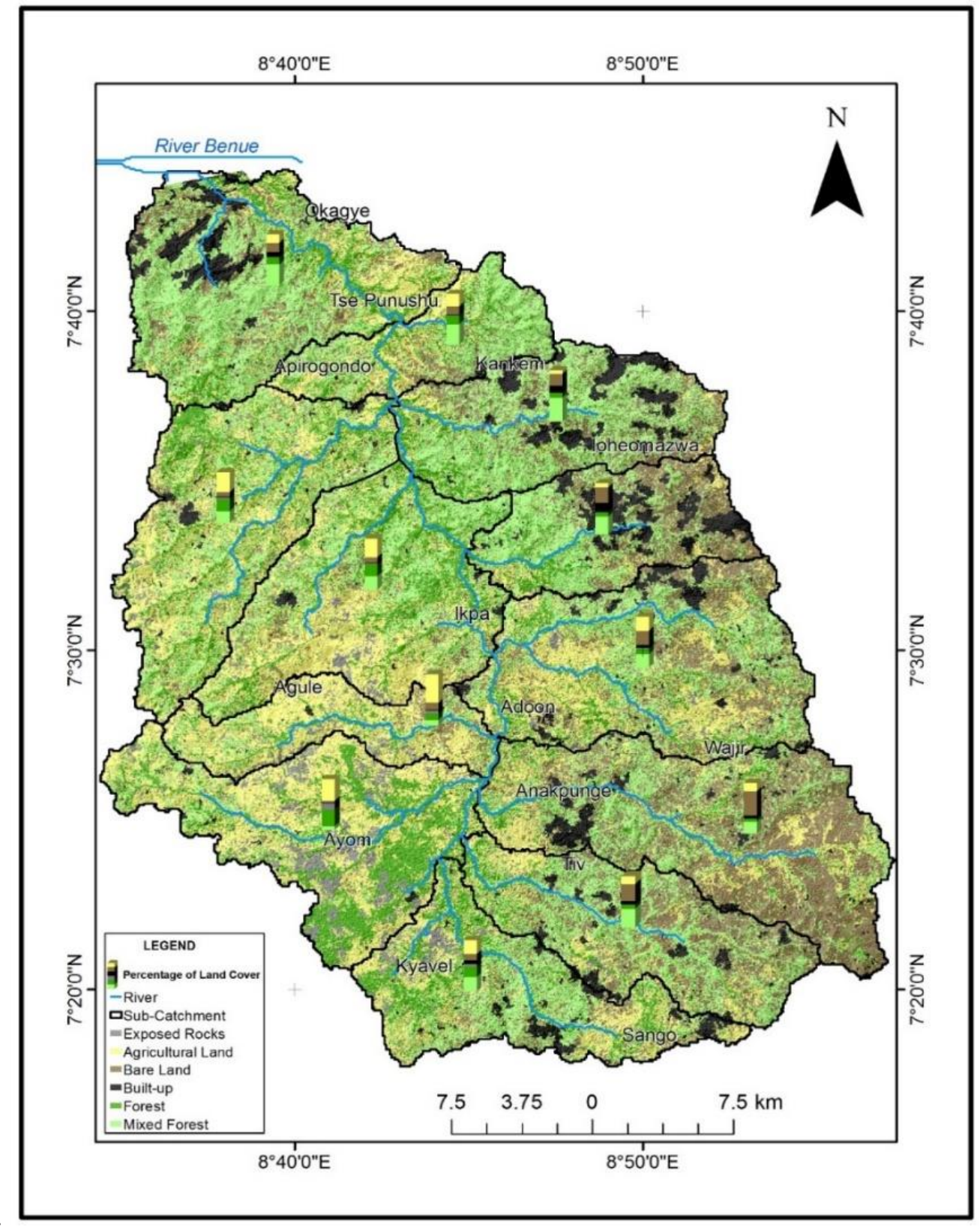

Figure 3: Land Cover Classes of 2016 for 12 Sub-catchments 
Ghana Journal of Geography Vol. 12 (2), 2020 pages 147- 168

\section{Global Correlation of Land Cover and Water Quality}

The Pearson's correlation was adopted to determine the existence of relationships between the water pollutants and land uses in the area. This was necessary because GWR could only function where there exists a relationship between the variables. Table 3 shows the Pearson's correlation coefficient between surface water pollutants and land use classes.

Table 3: Pearson Correlation Coefficient of Land Uses and Water Pollutants

\begin{tabular}{lllllll}
\hline $\begin{array}{l}\text { Water } \\
\text { pollutants }\end{array}$ & Agriculture & Built-up & $\begin{array}{l}\text { Bare } \\
\text { Land }\end{array}$ & Forest & $\begin{array}{l}\text { Mixed } \\
\text { Forest }\end{array}$ & Exposed Rocks \\
\hline Ammonia & 0.232 & -0.331 & 0.042 & 0.06 & -0.281 & 0.178 \\
Calcium & -0.257 & -0.084 & 0.043 & -0.152 & 0.502 & -0.287 \\
Chloride & -0.082 & 0.116 & 0.235 & -0.245 & 0.006 & -0.120 \\
DO & 0.101 & -0.159 & -0.297 & 0.429 & -0.112 & 0.254 \\
EC & 0.011 & -0.201 & 0.087 & -0.065 & 0.063 & -0.107 \\
Nitrate & -0.287 & 0.461 & -0.091 & -0.01 & 0.315 & 0.194 \\
pH & -0.385 & 0.231 & -0.089 & -0.047 & $0.657 *$ & -0.502 \\
Phosphate & -0.382 & 0.328 & 0.240 & -0.312 & 0.419 & -0.417 \\
Potassium & -0.06 & -0.062 & -0.349 & 0.308 & 0.252 & 0.25 \\
TDS & -0.261 & 0.09 & 0.293 & -0.336 & 0.282 & -0.25 \\
Temperature & -0.289 & 0.089 & 0.018 & -0.077 & 0.482 & -0.414 \\
Turbidity & 0.032 & -0.057 & -0.233 & 0.161 & 0.100 & 0.069 \\
\hline
\end{tabular}

Based on this analysis, it was observed that the percentage of mixed forest showed a significant positive correlation of $0.657(\mathrm{p}<0.05)$ with $\mathrm{pH}$.

\section{Spatial Variation of Relationships between Land Use Classes and Water Pollution}

The result of local $\mathrm{R}^{2}$ values for agricultural land use ranges between 0.0 and 0.5 with values of about 0.5 observed in the western parts of the study area where agricultural activities have the highest percentage (Figure 4a). This means that agriculture has a moderately strong relationship with $\mathrm{pH}$ in the area. The result also revealed that $\mathrm{pH}$ has a coefficient of variation (CV) of 9.52\%. In addition, the local $\mathrm{R}^{2}$ values of temperature, turbidity, $\mathrm{DO}, \mathrm{EC}, \mathrm{TDS}, \mathrm{NH}_{4}^{+}, \mathrm{K}^{+}, \mathrm{Ca}^{2+}, \mathrm{Cl}^{-}, \mathrm{NO}^{3-}$ 
Exploring the Spatial Variation of the Relationship between Land Use and Water Quality in a Drainage Basin Using Geographically Weighted Regression

and $\mathrm{PO}_{4}{ }^{3-}$ are below 0.3 , which showed that agricultural land use minimally contributed to the existing water study pollutants in the area. This implies that there is a weak association between agricultural land use and water pollution as most of the pollutants showed low $\mathrm{R}^{2}$ values.

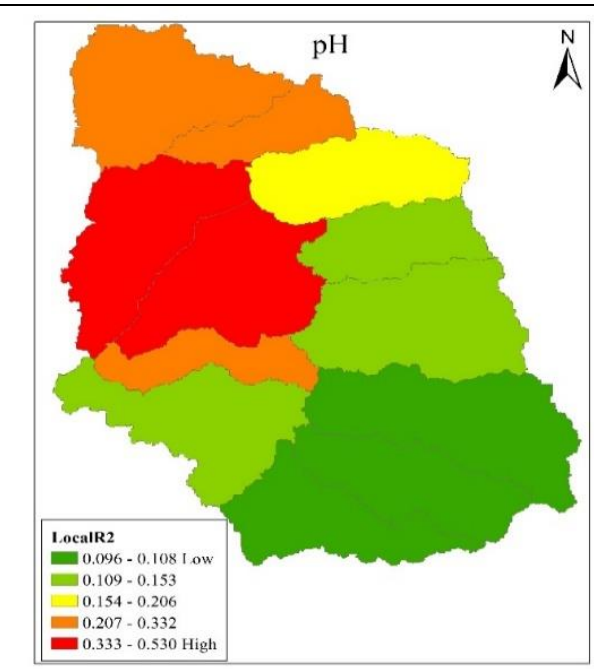

(a)

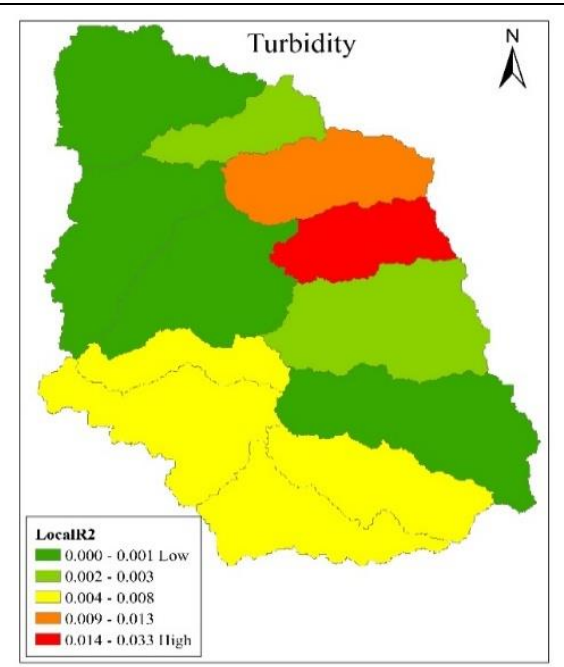

(b)

Figure 4 (a-b): Local $\mathrm{R}^{2}$ Values for Agricultural Land (not to Scale)

The result of local $\mathrm{R}^{2}$ values with respect to built-up areas is shown in Figure 5, where the results ranged from 0.0 to 0.38 .

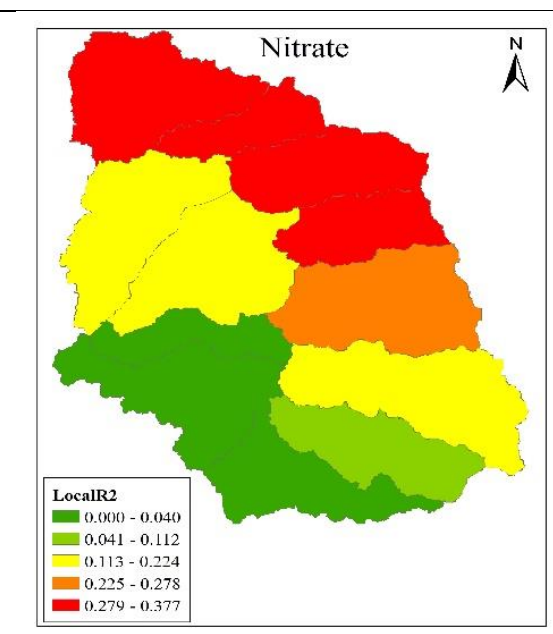

(a)

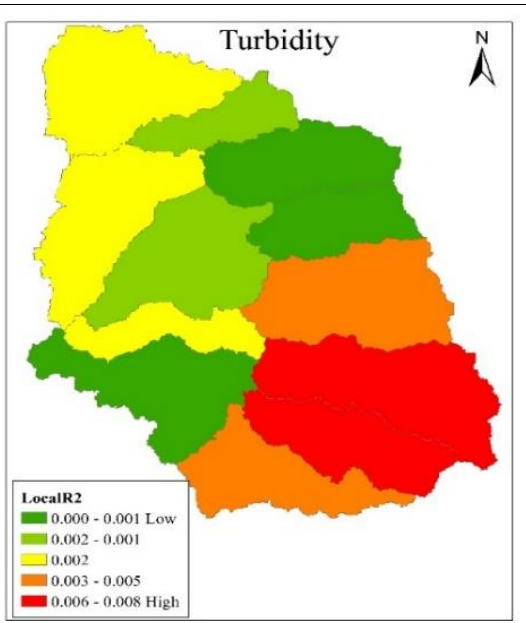

(b)

Figure 5 (a-b): Local $\mathrm{R}^{2}$ Values for Built-up Land (not to Scale) 
The local $\mathrm{R}^{2}$ values of about 0.38 were observed in the north-east region of the study area, with respect to nitrate, while low values (below 0.05) were observed in the south (Figure 5a). This is interpreted to mean that built-up area has a weak association in the area, and this applies to all the other parameters.

The local $\mathrm{R}^{2}$ values in Figure 6 show a range of 0 to 0.37 , with most of the pollutants (temperature, turbidity, $\mathrm{pH}, \mathrm{Ca}^{2+}, \mathrm{Cl}^{-}, \mathrm{NO}_{3}{ }^{-}$and $\mathrm{PO}_{4}{ }^{3-}$ ) having $\mathrm{R}^{2}$ values of less than 0.2 . This indicates that forest land use has a weak correlation with water pollution within the area. However, Figure 6 revealed that DO has a local $\mathrm{R}^{2}$ of about 0.37 recorded in the west while EC had $\mathrm{R}^{2}$ values of 0.3 observed in the northern parts of the area. The values of $\mathrm{R}^{2}$ varied all over the study area, indicating that the relationship was not homogeneous.

It was also noted that $\mathrm{R}^{2}$ values of 0.37 to 0.41 were observed across the central parts of the study area, while low $\mathrm{R}^{2}$ values of 0.17 to 0.19 were recorded in the north and west areas (Figure 6a). In Figure $6 \mathrm{~b}$, similar variation in $\mathrm{R}^{2}$ values were recorded across the west and south. These changes indicate that there exists spatial variation of relationships across the study area caused by the changes in land use.

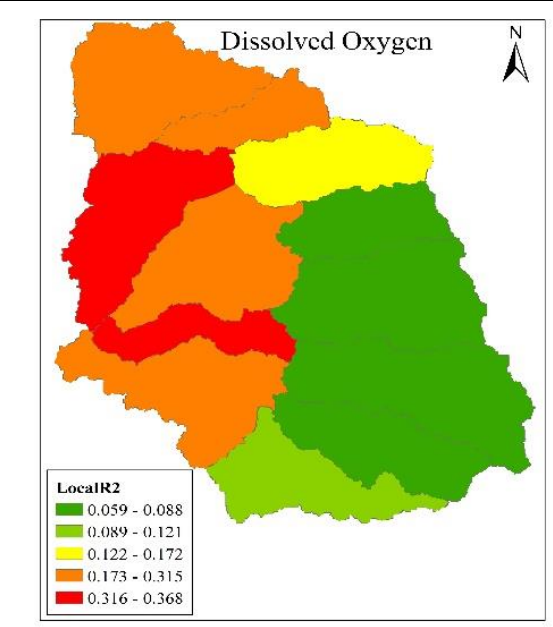

(a)

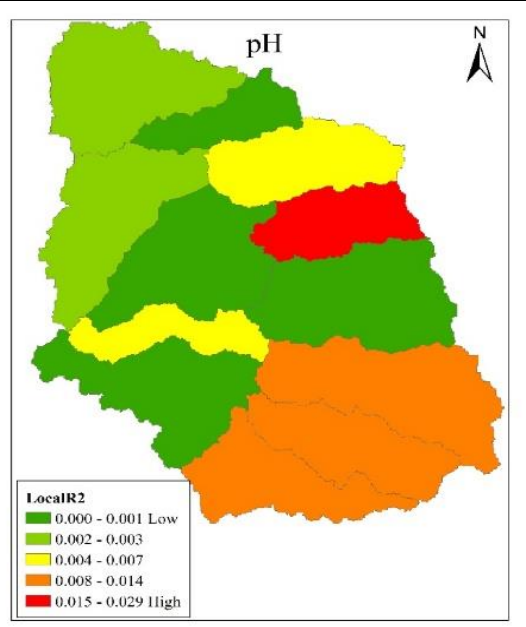

(b)

Figure 6 (a-b): Local $\mathrm{R}^{2}$ Values for Forest Land (not to Scale) 
Exploring the Spatial Variation of the Relationship between Land Use and Water Quality in a Drainage Basin Using Geographically Weighted Regression

Figure 7 shows the $\mathrm{R}^{2}$ values for mixed forest with respect to $\mathrm{pH}$ and $\mathrm{DO}$. The values of $\mathrm{R}^{2}$ shows high correlation with $\mathrm{pH}(0.5$ to 0.7$)$ in the west, while a low correlation was obtained in the southwest. This means that the forest has a high connection with water pollution in relation to $\mathrm{pH}$. It was also observed that some of the pollutants (DO, EC, turbidity, TDS, $\mathrm{Ca}^{2+}, \mathrm{Cl}^{-}, \mathrm{K}^{+}, \mathrm{NO}_{3}{ }^{-}, \mathrm{PO}_{4}{ }^{3-}$ ) had a weak association with water pollution due to their low $\mathrm{R}^{2}$ values in relation to mixed forest (Figure $7 b)$.

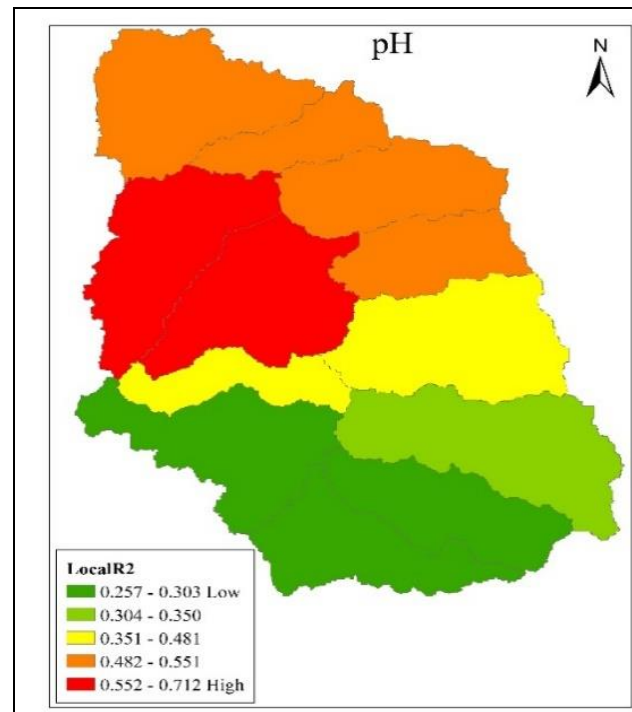

(a)

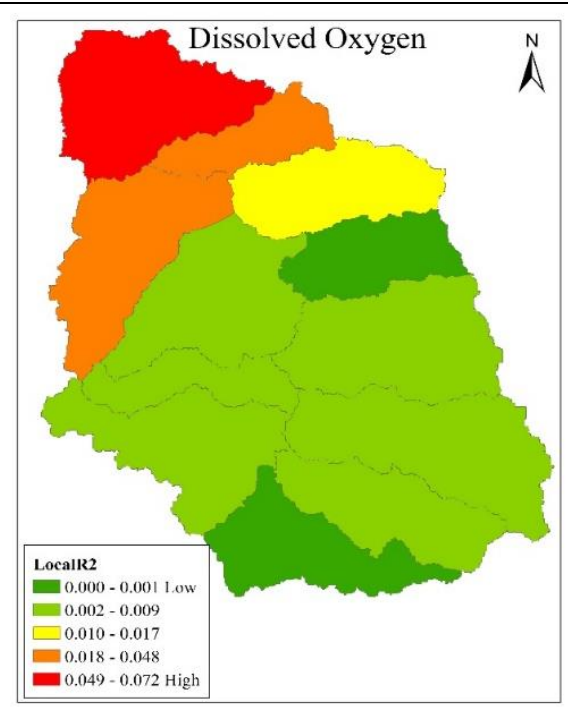

(b)

Figure 7 (a-b): Local $\mathrm{R}^{2}$ Values for Mixed Forest Land (not to Scale)

The result of the local $\mathrm{R}^{2}$ for bare lands with respect to EC and turbidity are shown in Figure 8 . The local $\mathrm{R}^{2}$ values ranged from 0.0 to 0.3 with most of the pollutants (temperature, turbidity, $\mathrm{pH}$, DO, TDS, $\mathrm{Ca}^{2+}, \mathrm{Cl}^{-}, \mathrm{NO}_{3}^{-}, \mathrm{PO}_{4}{ }^{3-}$ ) having $\mathrm{R}^{2}$ values of less than 0.2 . This shows that bare lands had a weak correlation with these pollutants in the area. There were also lower $\mathrm{R}^{2}$ values (below 0.1 ) observed in most parts of the drainage basin as can be seen in Figure 8b. This means that the value of $\mathrm{R}^{2}$ changed spatially for different land uses across the drainage basin. 


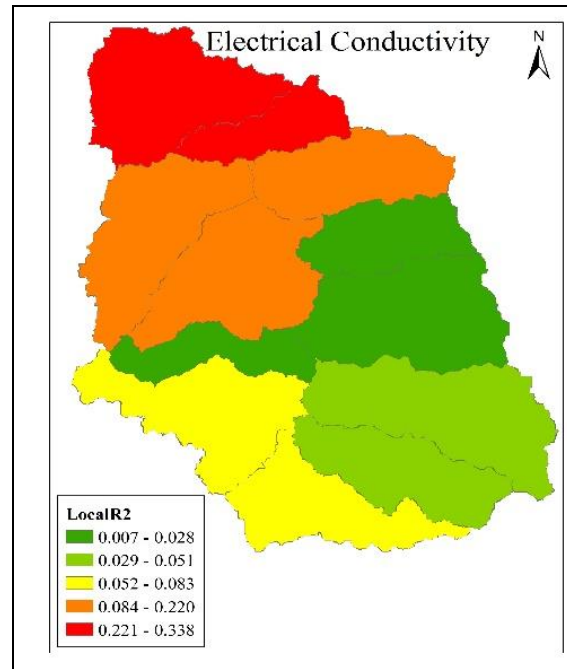

(a)

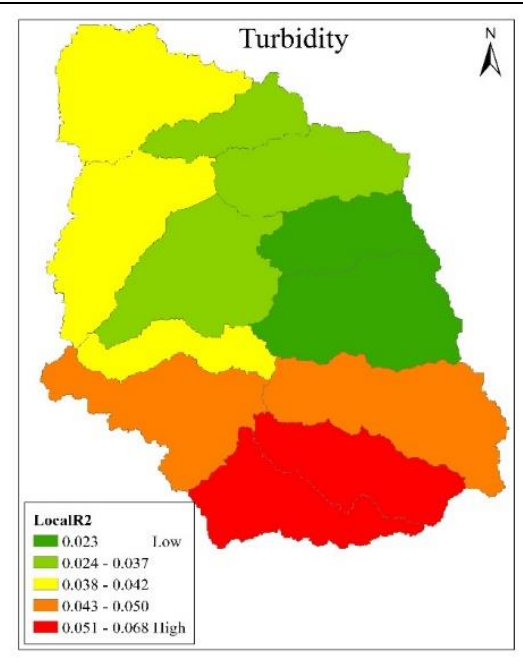

(b)

Figure 8 (a-b): Local $\mathrm{R}^{2}$ Values for Bare Land (Not to Scale)

\section{Discussion}

The results of local $\mathrm{R}^{2}$ values revealed a poor connection between agricultural land use and water pollution (Figure 4). This result corroborates the findings of Ding et al. (2015) in Dongjiang River Basin, South-eastern China. The result, however, differs from the submission of Tu (2011) and Huang et al. (2015) who reported that agriculture has a strong association with water pollution in Metropolitan Boston in eastern Massachusetts, USA and Southeast China, respectively.

The poor connection between these variables may be due to agricultural practices in the area. The major crops produced in the area are yam, cassava, soya beans, potatoes and rice, amongst others. It was observed from field investigation that the soil is fertile and that most of the farmers do not apply fertilizers in their farms because of the high cost involved in doing so. This means that the amount of pollutants washed by surface runoff into streams is low, which may be one of the reasons for the low level of pollutants in surface waters. Despite the weak association observed in this study, the concentration of water quality parameters in agricultural land use areas was higher than that in forest land use. This suggests that the impact of agricultural land use in terms of water pollution should not be ignored. 
Exploring the Spatial Variation of the Relationship between Land Use and Water Quality in a Drainage Basin Using Geographically Weighted Regression

Figure 5 reveals that the built-up area has a weak association with water pollution. This result is consistent with Ding et al. (2015) and Huang et al. (2015) who reported a similar relationship in southeastern and southern China, respectively. This may be due to the low amount of wastes discharged into the waters. In southern parts of the study area (Figure 5a), the percentage of builtup area is small and the contribution of built-up in this area, along with other parts of the drainage basin, may be due to domestic wastes such as refuse and animal wastes introduced into the rivers, which led to the pollution of water in the area. However, it was observed that though a weak relationship exists between built-up area and the pollutants, a more substantial relationship was observed between built-up and nitrate in the northern parts of the drainage basin. This may be due to the amount of domestic and industrial wastes discharged into the surface waters (Pratt and Chang, 2012; Ding et al., 2015). It is evident that such a relationship occurs as a result of wastes emanating from urban areas (Ahearn, Sheibley, Dahlgren, 2005).

The results also indicate that $\mathrm{R}^{2}$ values changed spatio-temporally for different land uses despite the fact that the drainage basin is an agro-based region. This may be due to the changes in the various land uses in the drainage basin.

Figure 6 shows a weak relationship between forest land use and pollution of water in the area. This result is consistent with many other research findings (Bahar et al., 2008; Lopez et al., 2008; Huang et al., 2015). This may be due to the low land use activities in forested areas, coupled with the high nutrient retention character of forests (Bahar et al., 2008; Gardner and McGlynn, 2009; Piatek et al., 2009; Bu, Tan, Li and Zhang, 2014; Huang et al., 2014). The variation in the local $\mathrm{R}^{2}$ values across the study area indicates that there exists a spatial varying relationship between the dependent and independent variables.

In Figure 7, the strong relationship between mixed forest water pollution in relation to $\mathrm{pH}$ may be due to anthropogenic activities such as the use of fertilizers on farmlands and wastes from animals such as cattle. However, most of the pollutants (DO, EC, turbidity, TDS, $\mathrm{Ca}^{2+}, \mathrm{Cl}^{-}, \mathrm{K}^{+}, \mathrm{NO}_{3}{ }^{-}, \mathrm{PO}_{4}{ }^{3-}$ ) had a weak association with water pollution due to their low $\mathrm{R}^{2}$ values in relation to mixed forest. 
Figure 8 shows that bare lands have a weak association with most of the pollutants in the study area. This may be attributed to limited anthropogenic influence in the area.

In general, the distribution of $\mathrm{R}^{2}$ values obtained in the drainage basin confirms that there exists a spatial varying relationship between land use and water quality in the River Mu basin. It was also observed that the highest $\mathrm{R}^{2}$ values for all the variables were found in the west and northern parts of the study area whereas low $\mathrm{R}^{2}$ values were recorded in the south.

A comparison of the spatial variation of these parameters showed that there were significant differences in $\mathrm{pH}(0.00)$, EC (0.00), turbidity (0.001), TDS (0.048), DO (0.003), $\mathrm{NH}_{4}^{+}(0.002)$, $\mathrm{Ca}^{2+}(0.00), \mathrm{Cl}^{-}(0.036), \mathrm{Fe}^{3+}(0.00)$ and $\mathrm{Cr}^{2+}(0.039)$ across the different stations (one-sample Kolmogorov Smirmov test-p<0.05), whereas $\mathrm{K}^{+}(0.134), \mathrm{PO}_{4}{ }^{3-}(0.715)$ and $\mathrm{NO}_{3}{ }^{-}(0.501)$ were not significantly different across the different stations (one-sample Kolmogorov Smirmov test$\mathrm{p}<0.05)$.

This study therefore contributes to knowledge by establishing that there exists a spatial varying relationship between anthropogenic activities and water quality in the study area. The relationship was identified and mapped at the local level using the GWR model. This has made possible the localization of the relationship to the sub-catchment rather than generalizing it for the entire area as was the custom in the past.

The implication of the spatial variation of the relationship between land use and water quality across the various sample sites is that the general treatment of water for the entire area will no longer be feasible because the quality of water in the drainage basin is not consistent but varies from one location to another depending on land use. In view of the inconsistency observed in this study, the following are recommended:

The GWR model should be applied in all the sub-drainage basins in the country to determine the relationship between variables at local scales. This will provide an insight into local relationships for decision-making and management. 
Exploring the Spatial Variation of the Relationship between Land Use and Water Quality in a Drainage Basin Using Geographically Weighted Regression

The study established that, land use and water pollutants vary spatially across the study area. This calls for the modification of the water management policies based on the various relationship identified in each sub-drainage basin. This will enhance the quality of water and the healthy living condition of the inhabitants.

There is a need to localize the procedure for water management to the sub-catchment and basin levels. This will help in providing adequate attention to each sub-catchment depending on the level of pollution identified.

\section{Conclusion}

GWR has proven to be an important tool in assessing the relationship between land use and water quality in the River Mu drainage basin. The findings revealed a weak relationship between land use and the water quality parameters, except for mixed forest and $\mathrm{pH}$, which had a moderately strong relationship. The variation of local $\mathrm{R}^{2}$ in the area is an indication that the relationship is inconsistent across the River Mu drainage basin.

\section{Acknowledgement}

We wish to appreciate the Staff of the Department of Water Resources and Environmental Management's Laboratory, Ahmadu Bello University, Zaria for undertaking the analysis of the physico-chemical parameters of water used in this study. 
Ghana Journal of Geography Vol. 12 (2), 2020 pages 147- 168

\section{References}

Ahaneku, I. E. and Animashaun, I. M. (2013). Determination of water quality index of River Asa, Ilorin, Nigeria. Advances in Applied Science Research, 4(6): 277-284.

Ahearn, D. S., Sheibley, R. W., Dahlgren, R. A. (2005). Land use and land cover influence on water quality in the last free-flowing river draining the western Sierra Nevada, California. Journal of Hydrology, 313(3-4): 234-247.

Akaahan, T. J. A., Leke, L. and Eneji, I. S. (2015). Seasonal Variation in hydro chemistry of River Benue at Makurdi, Benue State Nigeria. International Journal of Environment and Pollution Research, 3(3): 67-78.

American Public Health Association (APHA), (1999). Standard Methods for the Examination of Water and Wastewater. Published by American Public Health Association, American Water Works Association, Water Environment Federation.

Azua, S. (2018). Analysis of spatio-temporal variability of anthropogenic disturbances in River Mu drainage basin, Nigeria. Ph. D Thesis submitted to the School of Postgraduate Studies, Ahmadu Bello University, Zaria, Nigeria.

Badmus, B. S., Ozebo, V. C., Idowu, O. A., Ganiyu, S. A. and Olurin, O. T. (2014). Physicochemical Properties of Soil Samples and Dumpsite Environmental Impact on Groundwater Quality in South Western Nigeria. The African Review of Physics 9(0015): 103-114.

Bahar, M. M., Ohmori, H., Yamamuro, M. (2008). Relationship between river water quality and land use in a small river basin running through the urbanizing area of Central Japan. Limnology 9(19): 19-26.

Brown, S., Versace, V. L., Laurenson, L., Ierodiaconou, D., Fawcett, J., and Salzman, S. (2012). Assessment of spatiotemporal varying relationships between rainfall, land cover and surface water area using geographically weighted regression. Environmental Modeling and Assessment, 17(3): 241-254.

Bu, H., Tan, X., Li, S., Zhang, Q. (2014). Temporal and spatial variations of water quality in the jinshui river of the south qinling mts., China. Ecotoxicology and Environmental Safety, 73(5): 907-913.

Chang, H. (2008). Spatial analysis of water quality trends in the Han River basin, South Korea. Water Research, 42(13): 3285-3304.

Chu, H., Liu, C. and Wang, C. (2013). Identifying the Relationships between Water Quality and Land Cover Changes in the Tseng-Wen Reservoir Watershed of Taiwan. International Journal of Environmental Research and Public Health, 10: 478-489, doi:10.3390/ijerph10020478.

Ding, J., Jiang, Y., Fu, L., Liu, Q., Peng, Q. and Kang, M. (2015). Impacts of land use on surface water quality in a Subtropical River Basin: A case study of the Dongjiang River Basin, Southeastern China. Water 7(8): 4427-4445. doi:10.3390/w7084427.

Elaigwu A.M., Okayi R. G. and Oshoke, J. (2013). Assessment by Parameter Quality Function of Mu River, Makurdi, Nigeria. Nigerian Journal of Fisheries, 10(1 \& 2): 618-626.

Eneji, I. S., Onuche, A. P. and Sha'Ato, R. (2012). Spatial and Temporal Variation in Water Quality of River Benue, Nigeria. Journal of Environmental Protection, 3: 915-921 http://dx.doi.org/10.4236/jep.2012.328106.

Fotheringham, A. S., Brunsdon, C. and Charlton, M. (2002). Geographically weighted regression: the analysis of spatially varying relationships. John Wiley \& Sons, Chichester. 
Exploring the Spatial Variation of the Relationship between Land Use and Water Quality in a Drainage Basin Using Geographically Weighted Regression

Gardner, K. K. and McGlynn, B. L. (2009). Seasonality in spatial variability and influence of land use/land cover and watershed characteristics on stream water nitrate concentrations in a developing watershed in the rocky mountain west. Water Resources Research, 45: 1-14.

Gyawali, S., Techato, K., Yuangyai, C. and Musikavong, C. (2013). Assessment of relationship between land uses of riparian zone and water quality of river for sustainable development of river basin, A case study of U-Tapao river basin, Thailand. Procedia Environmental Sciences 17: 291-297.

Huang, J., Huang, Y., Pontius Jr., R. G. and Zhang, Z. (2015). Geographically weighted regression to measure spatial variations in correlations between water pollution versus land use in a coastal watershed. Ocean \& Coastal Management 103:14-24.

Hula, M. A. (2010). Population dynamics and vegetation change in Benue State, Nigeria. Journal of Environmental Issues and Agriculture in Developing Countries, 2(1): 53-69.

Ismaila, A. B. (2013). Evaluating land use change in rapidly urbanizing nigeria: Case study of Yola, Adamawa State. GIS Ostrava 2013 - Geoinformatics for City Transformation. January 21-23.

Javi, S. T., Malekmohammadi, B. and Mokhtari, H. (2013). Application of geographically weighted regression model to analysis of spatiotemporal varying relationships between groundwater quantity and land use changes (case study: Khanmirza Plain, Iran). Environmental Monitoring and Assessment, 186(5):3123-3138. DOI 10.1007/s10661-013-3605-5.

Kilonzo, F., Masese, F. O., Griensven, A. V., Bauwens, W., Obando, J. and Lens, P. N. L. (2014). Spatial-temporal variability in water quality and macro-invertebrate assemblages in the upper Mara River basin, Kenya. Physics and Chemistry of the Earth, 67-69: 93-104.

Li, Y. F., Song, G. H., Wu, Y. G. (2009). Evaluation of water quality and protection strategies of water resources in arid-semiarid climates: a case study in the Yuxi River Valley of Northern Shanxi Province, China. Environmental Geology, 57(8): 1933-1938.

Lloyd, C. D. (2010). Analysing population characteristics using geographically weighted principal components analysis: A case study of Northern Ireland in 2001. Computers, Environment and Urban Systems 34: 389-399.

Lopez, R. D., Nash, M. S., Heggem, D. T. (2008). Watershed vulnerability predictions for the Ozarks using landscape models. Journal of Environmental Quality, 37(5): 1769-1780.

Lu, P., Mei, K., Zhang, Y., Liao, L., Long, B., Dahlgren, R. A. and Zhang, M. (2011). Spatial and temporal variations of nitrogen pollution in Wen-Rui Tang River watershed, Zhejiang, China. Environmental Monitoring and Assessment, 180: 501-520.

Nageswara, P. P. R., Shobha, S. V., Ramesh, K. S. and Somashekhar, R.K. (2005). Satellite -based assessment of agricultural drought in Karnataka State, Journal of the Indian Society of Remote Sensing, 33(3): 429-434.

Naibbi, A. I. and Healey, R. G. (2014). Using geographically weighted regression to estimate the spatial patterns of fuelwood utilization in Nigeria. American Journal of Geographic Information System, 3(3): 109-121 DOI: 10.5923/j.ajgis.20140303.01.

National Population Commission (2006). Retrieved from http://www.population.gov.ng/index.php/about-npc Accessed on $20^{\text {th }}$ June, 2019

Okwoche, V. A., Age, A. I. and Alegwu, F. O. (2012). Assessment of youth's participation in agriculture and rural development, Benue State, Nigeria. Agricultural Journal, 7(5): 365-369. 
Ologunorisa T. E. and Tor, T. (2006). The changing rainfall pattern and its implication for flood frequency in Makurdi, Northern Nigeria. Journal of Applied Sciences and Environmental Management, 10(3): 97-102.

Piatek, K. B., Christopher, S. F. and Mitchell, M. J. (2009). Spatial and temporal dynamics of stream chemistry in a forested watershed. Hydrology and Earth System Sciences, 13: 423-439.

Pratt, B., Chang, H. (2012). Effects of Land Cover, Topography, and built structure on seasonal water quality at multiple spatial scales. Journal of Hazardous Materials, 209-210: 48-58.

Roberts, A. D., Prince, S. D. (2010). Effects of urban and non-urban land cover on nitrogen and phosphorous runoff to Chesapeake Bay. Ecological Indicators, 10(2): 459-474.

Sabokbar, H. F., Roodposhti, M. S. and Tazik, E. (2014). Landslide susceptibility mapping using geographically-weighted principal component analysis. Geomorphology, 226: 15-24.

Su, S., Xiao, R., and Zhang, Y. (2012). Multi-scale analysis of spatially varying relationships between agricultural landscape patterns and urbanization using geographically weighted regression. Applied Geography, 32(2): 360-375.

Sun, Q. Q., Huang, J. L., Hong, H. S. (2011). Analysis on linkage between farm landscape and water quality in Jiulong River watershed. Trans. Case 27(4): 54-59.

Tran, C. P., Bode, R. W., Smith, A. J., (2010). Land-use proximity as basis for assessing stream water quality in New York State (USA). Ecological Indicators, 10(3): 727-733.

Tu, J., Xia, Z. G., Clarke, K. C., (2007). Impact of urban sprawl on water quality in Eastern Massachusetts, USA. Environmental Management, 40 (2): 183-200.

Tu, J. (2011). Spatially varying relationships between land use and water quality across an urbanization gradient explored by geographically weighted regression. Applied Geography, 31(1): 376-392. 